\title{
IMPOLITENESS STRATEGY IN INSTAGRAM CYBERBULLYING: A CASE STUDY OF JENNIFER DUNN POSTED BY@LAMBE_TURAH
}

\author{
Fani Indrawan \\ Indrawan.sch@gmail.com \\ Universitas Airlangga
}

\begin{abstract}
Social media is used by most Indonesian people. Social media brings good and bad influence. One of the bad influences is cyberbullying. Cyberbullying that is found in Instagram is the most different from other social media. Instagram has become the source of hate campaign by the occurrence of gossip account. @Lambe_turah is one of the biggest gossip accounts in Indonesia.The posts in @Lambe_turah have triggered its followers to perform cyberbullying to the person in their post. The victim of cyberbullying who became the focus of this research was Jennifer Dunn. The aim of this study was to investigate the comments which contain cyberbullying by using impoliteness strategy proposed by Culpeper (2005). This study uses qualitative approach. It is shown by the data collection method which was done by examining documents. The analysis of this study was done by interpreting the collected data. The result showed that negative impoliteness was the most common impoliteness strategy to be used in cyberbullying. The second impoliteness strategy that was used in cyberbullying was bald on record. From both of these strategies, it could be concluded that cyberbullying tend to attack the addressee directly by using various types of statements.
\end{abstract}

Keywords: Impoliteness; Cyberbullying; Instagram

\begin{abstract}
Abstrak
Media sosial digunakan oleh sebagian besar orang Indonesia. Media sosial membawa pengaruh baik dan buruk. Salah satu pengaruh buruknya adalah cyberbullying. Cyberbullying yang ditemukan di Instagram adalah yang paling berbeda dari media sosial lainnya. Instagram telah menjadi sumber kampanye kebencian dengan adanya akun gosip. @Lambe_turah adalah salah satu akun gosip terbesardi Indonesia.Unggahandi@Lambe turah telah memicu pengikutnya untuk melakukan penindasan di dunia maya ke orang $\overline{d i}$ unggahan mereka. Korban cyberbullying yang menjadi fokus penelitian in adalah Jennifer Dunn. Tujuan dari penelitian ini adalah untuk menyelidiki komentar yang mengandung cyberbullying dengan menggunakan strategi ketidaksopanan yang diajukan oleh Culpeper (2005). Penelitian ini menggunakan pendekatan kualitatif. Hal ini ditunjukkan dengan metode pengumpulan data yang dilakukan dengan menganalisa dokumen. Analisis penelitian ini dilakukan dengan menginterpretasikan data yang dikumpulkan. Hasilnya menunjukkan bahwa ketidaksopanan negatif adalah strategi ketidaksopanan yang paling umum untuk digunakan dalam cyberbullying. Strategi ketidaksopanan kedua yang digunakan dalam cyberbullying bald on record. Dari kedua strategi ini, dapat disimpulkan bahwa cyberbullying cenderung menyerang penerima secara langsung dengan menggunakan berbagai jenis pernyataan.
\end{abstract}

Keywords: Ketidaksopanan, Cyberbullying; Instagram 


\section{INTRODUCTION}

The use of social media in these past years is growing rapidly. Almost everyone has an account in social media. The data from Ministry of Communication and Informatics states that internet users in Indonesia reaches 63 million people which $95 \%$ of that number is using internet for social media (Kemenkominfo, 2018). From this data, it can be concluded that social media has become an important part of daily life for Indonesian people. From one perspective, it may be a good thing, because it implies that Indonesian people follows the technological advancement. By having social media, people can connect with their friends, family, or colleague without having to meet them in person. However, social media may also bring bad influence. One of the bad influences is cyberbullying.

Cyberbullying refers to an act of bullying which happen in instant messaging, email, chat room, website, video game, or through a picture or message sent through a phone (Kowalski, 2008). This act is found almost in all kind of social media. In the previous definition, it can be implied that cyberbullying does not happen in physical environment but it occurs in cyber instead. Happening in cyber, cyberbullying may not cause any physical damage, but it may cause psychological damage to the victim, such as depression, low self-esteem, even could lead to suicide (Hinduja and Patchin, 2010). The effect is dangerous to the victim because at an extreme level, the victim may get suicidal idea or in more extreme level they commit suicide for real. One example of cyberbullying victim that committed suicide is Rebecca Sedwick. Rebecca is a twelve years old girl who experiences cyberbullying from her friends in the form of electronic messages. The messages contain hatred and demand for her to commit suicide. After one year withstanding cyberbullying, she committed suicide. In Indonesia, one of cyberbullying cases is Sonya Depari. She experiences cyberbullying from netizens which mock and abuse her from her social media. Those experiences have made her trauma. From both examples, although cyberbullying is not physically happened to them, but cyberbullying contributes to their suffering.

Cyberbullying can be found in many kind of social media. Compared to other social media, Instagram has different ways of cyberbullying (Hosseinmardi, et al., 2015). Instagram is a social media that was built especially for mobile that allows users to post image or video and comment to other users' post. With these features, users can use it to perform cyberbullying to other users. Hosseinmardi, et al. (2015) said that cyberbullying in instagram can happen by posting humiliating image of someone by editing the image, posting hateful comments, an aggressive caption directed to someone or group, or creating fake account by pretending to be someone else. By mentioning various types of cyberbullying that can be found in instagram, the writer is 
interested to see the cyberbullying in it especially in comment section.

Cyberbullying in Instagram is mostly found in the comment section. It is because in comment section users can react and reply to other users' comments. The users tend to leave an aggressive comment on controversial posts or on posts by controversial people. In Indonesia, an interesting phenomena related to Instagram cyberbullying has occurred. The phenomena is the appearance of gossip account. This account only updates about interesting news related to celebrities and controversial persons or news. The posts from gossip account are mostly negative or controversial about particular topic or persons. These posts will trigger its follower to react and comment. By updating about controversial posts, the gossip account on Instagram has become the source of hate campaign in social media. The interesting factor is the number of followers of the gossip account is big and increasing. People follow gossip accounts to get the latest update from celebrities or other controversial or interesting news so they can judge or even blame. One of the biggest gossip accounts is @lambe turah. It has 4.4 million active followers who are always active and comments on each update.

This research aims to investigate cyberbullying in the comments section in gossip account “@lambe_turah" from impoliteness perspective. Culpeper (2005) defines impoliteness as a negative attitude toward specific behaviors in specific contexts which is sustained by expectations, desires and/or beliefs about social organization, including how one person's or group's identities are mediated by others in interaction. This definition is interesting because cyberbullying and impoliteness perform negative attitude toward the addressee. Having similar attitude tendency, it is interesting to find out which impoliteness strategy is the most common to be used in cyberbullying.

\section{THEORETICAL FRAMEWORK}

In society, people will always interact to each other. These social interactions include the linguistic interaction. Interaction between society members could only be achieved when the members have competence in understanding the language. In social interaction, there are norms and values about how we have to behave in society which we call it as politeness. Yule (1996) calls the interaction as 'polite social behavior', which has two factors that are related to this term, social distance and closeness. In society where we are bounded to a condition that people have different social status and age, we are forced to have different social distance and closeness regarding the conditions above. These factors influence how they use language based on social differentiation. For example, in Indonesia, when people are talking to someone who has higher social status or much older, they use 'Pak' or 'Bu' to address to the person to show their respect. This act is considered as face saving act because the speaker wants 
to show their awareness to other people's face.

The culture values and norms have a concept of what is polite and impolite. If politeness is basically about face saving acts, the inversion, impoliteness will have the opposite definition. Culpeper (2005) defines impoliteness as "communicative strategies designed to attack face, and thereby cause social conflict and disharmony". From the definition we can see that impoliteness refers to the acts that are intentionally done to attack someone's face to cause disharmony. Impoliteness can be found in any behavior shown by the language user. It can be found in everyday conversation, in office interaction, in school interaction, and many others. All of the acts that are supposedly done by the language user to attack face are considered as impoliteness. One of the society's act that clearly containing impoliteness is bullying. Since we are now living in digital era, bullying is also entering new era of cyberbullying.

Greene in Erdur-Baker (2010) defines the differences between traditional and cyber bullying which are shown by the three implicit assumptions below:

1. The victims know who their bullying is;

2. There is a power imbalance between the victim and the bullies; and

3. Bullying occurs on and around school grounds.

The difference between traditional bullying and cyberbullying is almost clear that mostly in cyberbullying the victims do not know who the bully is. Since cyber is one of the computer-mediated communications which the interaction does not need to meet in person, this condition could possibly be happened. The use of computer in the interaction and communication brings the most distinguished factors from traditional bullying and cyberbullying. With the technology (personal computer, gadget, etc), people could access and interact with the others as long as they are connected to the internet. Wade and Beran (2011) conclude cyberbullying as "intentional acts of aggression - or intentional acts causing harm toward someone else - that are perpetrated via an electronic medium". Parks (2013) also explains the method used in cyberbullies:

"Cyberbullies use to taunt and torment their victims differ on the basis of the people involved and the types of media used. Harassment, for instance, involves the continuous badgering of someone with offensive, insulting, and/or threatening messages through instant messaging, e-mail, or cell phone texting."

Locher (2010) said that there were two types of computer-mediated communication, namely synchronous means (e.g. chat) and asynchronous means (e.g. blog, facebook, Instagram). The differentiation is based on how the conversation in CMC applies the rules of conventional conversation structure. Synchronous (Chatting) could apply the rules of usual conversation structure since in chats, the doer (two 
persons or multiple persons) could replying in other in a real time, just like how the usual conversation does and it is different from the asynchronous one. The writer puts Instagram as the object of the research because people use Instagram as the media to share their aspects of everyday life which can be seen and responded by other users. It is also the second highest percentage of where cyberbullying takes place with the percentage of 23.4\% (Cyberbullying/Bullying Statistics, 2006).

Usually in traditional bullying there is a power imbalance between the victim and the bully, but when it comes to cyberbullying, there is no need to have power imbalance to do cyberbullying. Cyberbullying could be done to anyone. In Indonesia, people usually bully those who are public figure in the society or those who are controversial. Public figure and controversial behavior are often found in the characteristic of celebrity. Boorstin (in Turner, 2004) defines celebrity as "a person who is well-known for their well-knowness". People are likely to comment, criticize or even bully them based on how they behave in their daily life. It is because all of their behavior and habit can be seen and 'consumed' by the society which leads to cyberbullies.

After understanding the concept of cyberbullies above, it is interesting to analyze the phenomena of cyberbullies done by Instagram users. The writer analyzed the comments made by Instagram users which contained bullies by using five impoliteness strategies proposed by Culpeper (2005). Culpeper (2005) defines impoliteness as a negative attitude toward specific behaviors in specific contexts which is sustained by expectations, desires and/or beliefs about social organization, including how one person's or group's identities are mediated by others in interaction. From this definition, there is an interesting factor related to cyberbullying and impoliteness. Cyberbullying aims to do negative act to people by doing harassing, abusing, insulting, and many others. Impoliteness is also a negative act towards the addressee. Having similar attitude tendency, it is interesting to find out which impoliteness strategy is the most common to be used in cyberbullying. This study will use the classification of impoliteness strategy by Culpeper (2005). The classification are: bald on record impoliteness, positive impoliteness, negative impoliteness, sarcasm or mock politeness, and withhold politeness. Those five impoliteness strategies are explained in more detailed as follows (Culpeper, 2005):

Bald on record impoliteness: the FTA (face threatening act) is performed in a direct, clear, unambiguous, and concise way in circumstances where face is not irrelevant or minimized.

Positive impoliteness: this strategy is used to damage the addressee's positive face that they want, e.g., ignore the other, exclude the other from an activity, be disinterested, unconcerned, unsympathetic, use inappropriate identity markers, use 
obscure or secretive language, seek disagreement, use taboo words, call the other names.

Negative impoliteness: the use of strategies designed to damage the addressee's negative face wants, e.g., frighten, condescend, scorn or ridicule, be contemptuous, do not treat the other seriously, belittle the other, invade the other's space (literally or metaphorically), explicitly associate the other with a negative aspect (personalize, use the pronouns "I" and "You"), put the other's indebtedness on record.

Sarcasm or mock politeness: the FTA is performed with the use of politeness strategies that are obviously insincere, and thus remain surface realizations.

Withhold politeness: the absence of politeness work where it would be expected. For example, failing to thank somebody for a present be taken as deliberate impoliteness.

\section{METHODOLOGY}

This research aimed to analyze the impoliteness strategies that were used by Instagram users when they committed cyberbullying. This research used qualitative approach to find out the behavior, perspective and performance of impoliteness by Instagram users. Qualitative research collects data by examining documents, observing behavior or interviewing participants (Creswell, 2009). This research used documents which are the comments by Instagram users which can also be used as the users behavior indicator as the source of data. Qualitative approach in this research was represented in the interpretative analysis.

The data were taken from one of the most popular social media in the world, Instagram. In Indonesia, Instagram is the most popular social media because it is used by many people in daily life. Instagram users use Instagram for various purposes. One of the phenomena related to Instagram is the appearance of gossip account. Gossip account is an Instagram account that only updates about interesting news related to celebrities or other important persons or even controversial persons or news. The news from gossip account are mostly negative that are purposed to entertain the followers about particular topic or person. With this characteristic, the updates will likely to trigger people to comment. By always updating about negative news, the gossip account is becoming the source of hatred in social media.

One of the biggest gossip accounts is @lambe_turah. It has 4.4 million active followers who always comment on their updates. The researcher selected a post with the highest engagement from the followers. The writer limited the data by selecting the post from November 2017 to January 2018 because it was considered the latest news in Indonesia. The average comment was ranging from 1000 to 3000, but the 
researcher found a post that had more than 14.000 comments and thus it was chosen to become the sources of data in this research. However, the writer did not use all 14.000 comments. The writer limited the data to only the latest 1000 comments with consideration that those comments were the newest reactions. The post was about the news (video) of Jennifer Dunn being arrested by police for the possession of drugs. That post became the most commented post in @Lambe_turah. After the collection of data was sufficient, the writer then classified them based on characteristics of five strategies that were proposed by Culpeper (2005). The data must be read carefully to determine which category each comment belongs. The data that was not fit to five impoliteness strategies (did not contain cyberbullying) were eliminated.

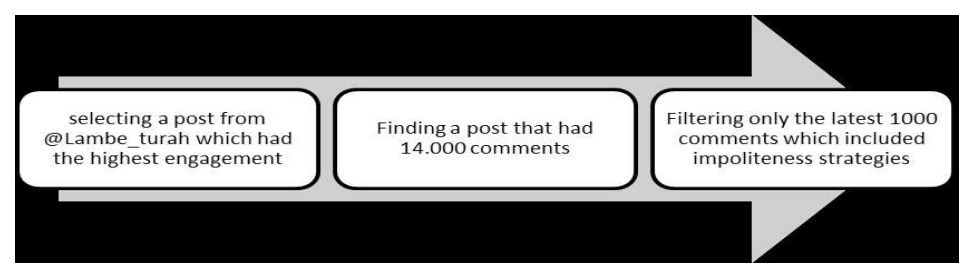

Figure 1: Data Collection Process

After finding the data and categorizing them by those five strategies, the writer calculated the number and the percentage of data findings. Then the writer put them into table 1 which sorted them by the categories. After that, the writer analyzed the findings data on each category to interpret how the issue was related to the theories and how the theories gave implication in real world. The analysis was based on the writer interpretation and combined it with the five impoliteness strategies by Culpeper (2005).

\section{FINDINGS AND DISCUSSION}

From one post in @lambe_turah that had more than 14.000 comments, the writer selected the comments that contained cyberbullying in the latest 1000 posts. They were selected as they were considered the newest interaction in the comment section. The posts were calculated and categorized based on Culpeper's (2005) impoliteness strategies. From the five strategies proposed by Culpeper (2005), Indonesian Instagram users mostly used negative impoliteness in bullying the objects. The second mostly used in Instagram cyberbullies was bald on record impoliteness. Then it was followed by positive impoliteness and sarcasm or mock impoliteness. The last strategy proposed by Culpeper (2005), withhold politeness, was not found in Instagram cyberbullies. To get a clear understanding of the findings, the categories were presented in Table 1: 


\begin{tabular}{|c|l|c|c|}
\hline No & \multicolumn{1}{|c|}{ Model of Impoliteness } & Number of Findings & Percentage \\
\hline 1 & Bald on Record Impoliteness & 232 & $26.7 \%$ \\
\hline 2 & Positive Impoliteness & 208 & $24 \%$ \\
\hline 3 & Negative Impoliteness & 369 & $42.6 \%$ \\
\hline 4 & Sarcasm or Mock Politeness & 58 & $6.7 \%$ \\
\hline 5 & Withhold Politeness & 0 & $0 \%$ \\
\hline & TOTAL & 867 & $100 \%$ \\
\hline
\end{tabular}

Table 1. Findings of Impoliteness Strategies in Instagram Cyberbullies

\section{Bald on Record Impoliteness}

This model of impoliteness was the harshest way and the most straightforward in addressing impoliteness to the face. In this model the face threatening act was performed in a direct and obvious way. Culpeper (2005) defined Bald on Record Impoliteness as the FTA that was performed in a direct, clear, unambiguous, and concise way in circumstances where face was not irrelevant or minimized. From Culpeper (2005) definition, this type of impoliteness did not consider the face of the addressee. The addresser said something straightforward without any barrier to addressee.

Regarding on how the impoliteness was being delivered in this type, harsh and rude could be the best definition to represent this model. Based on the findings, the writer found 232 comments that contained bald on record impoliteness with the percentage of $26.7 \%$. This number went to the second rank after negative impoliteness. It indicated that cyberbullying in Instagram were likely to use bald on record strategy to attack the addressee. Based on the result in Table 1, bald on record was quite common to be applied in performing cyberbullies.

From table 1, to give more detailed explanation and example of how the bald on record strategy was used by instagram user to perform cyberbullying, some extracts of comments containing this impoliteness strategy was presented below:

\section{Petsh*******: Udah $3 x$ ngak kapok manusia macam apa ini}

The context from Petsh******* comment was that JD had ever been caught in similar case before JD was arrested again for the third time. The comments implied that JD had done this case and it had happened twice. With this case, it had already happened three times. That background made Petsh******* felt irritated of JD. Petsh******* thought that after being arrested twice, JD must realize that what she did was wrong. Petsh $* * * * * * *$ also indicated that normal human would realize their mistake after two times doing the same mistakes. Since JD had repeated the same mistake, Petsh******* could not understand what kind of human JD was. In this 
context, Petsh******* attacked JD's face straightly by stating the previous similar cases done by JD and implied that JD was not normal as human (in negative way). Petsh ${ }^{* * * * * * *}$ statement was considered as bald on record because Petsh******* stated that JD was not normal by saying what kind of human will act like JD. The statement was delivered in a clear, unambiguous, and obvious way to damage the face of Jennifer Dunn.

2. Cal***: Mampus pelakor di tangkap...tuhan tidak diam apa yang kamu rusaak rumah tangga org kena batunya

The context of Cal*** comment is that JD is a 'pelakor' that make her being hated by most of @Lambe_turah followers. Pelakor is a new Indonesian terms which stands for "perebut lelaki orang" that can be translated into English as a "husband snatcher". In this comment, Cal*** did not only addressing JD as a husband snatcher, but also added very strong rude word "mampus". Mampus is common to be addressed to animal or a person with very bad behavior so they are associated to animal. In this context, Mampus as used to show an expression of relief that JD, the one who was a husband snatcher, was involved in drugs and arrested. Cal*** added that God was always fair that the one who did wrong would pay for the sin eventually. Related to the context that JD was a husband snatcher, $\mathrm{Cal}^{* * *}$ asserted that what happen to JD was caused by her sin for snatching someone's husband. In this statement, Cal*** deliberately showed her anger to other@lambe_turah followers that JD deserved to get arrested for all of the sins that she had done to other especially the wife of husband that JD had snatched. Cal*** statement could be considered bald on record because the statement was delivered in a clear, unambiguous, and obvious way to damage the face of Jennifer Dunn. Not only that, $\mathrm{Cal}^{* * *}$ used this strategy several times in a sentence. Some of the words that were used by $\mathrm{Cal}^{* * *}$ were mampus, pelakor, and kena batunya. All of them were delivered clearly to attack JD's face.

\section{3. amyna****** : Mampuuuussss loe ...makan tu karma}

The context in the third example was similar to the previous example that JD was a husband snatcher. Amyna****** was also using word "mampus" with more emphasis by adding more $\mathrm{u}$ letter to emphasis the emotion. In $\mathrm{CMC}$, the expression of addresser is delivered by the use of emoticons, by using capitalized letter to show anger or by adding more letter to stress the word and show the anger. Amyna****** applied this strategy to stress that JD deserved for getting caught by the police so she emphasized that message by adding more ' $u$ '. Amyna****** also added the word loe to address to JD. Loe is a more informal addressing variation for 'you'. It is usually used to show that someone is angry or to address to someone which has close relationship, or to show no respect to other person. In this context, loe was used with 
purpose to address without respect and Amyna****** as the addresser was angry with JD. In the last part of the comment, Amyna****** said that it was the karma of what JD had done, which was snatching away someone's husband. Karma is Indonesian term which means the result of human's action. If one has done something bad, he/ she will get punished, that is karma. The statement from Amyna****** was delivered in a clear, unambiguous, and obvious way to damage the face of Jennifer Dunn so it categorized as bald on record.

\section{Positive Impoliteness}

The second model is positive impoliteness. The purpose of this strategy is to damage the addressee's positive face wants. Culpeper (2005) defined positive impoliteness as an act to damage the addressee's positive face wants, e.g., ignore the other, exclude the other from an activity, be disinterested, unconcerned, unsympathetic, use inappropriate identity markers, use obscure or secretive language, seek disagreement, use taboo words, call the other names. Based on Culpeper (2005) definition, there are many type of positive impoliteness strategy. In the findings (table 1), positive impoliteness was found 208 times with the percentage of $24 \%$. This number was still below bald on record impoliteness strategy. Based on the table, positive impoliteness strategy was les-common to be used in cyberbullying. Some of the findings will be discussed below:

1. Diaries**** : nah elu apa namanya manusia yang jenis kelaminnya ga jelas.. ngefans sm artis. masuk ke akun haters. dungu(?)

This was an interesting finding because one of the participants showed disagreement to the other participants. The context in this comment was Diaries****'s reaction to the previous comment made by other commenter that say that he/she was supporting JD. It is common to find some argument from the commenter in comment section between the pro side and contra side. Diaries**** was contra and dislike JD so Diaries**** reacted to someone who were on the opposite side. Diaries**** said that @Lambe_turah was the community for haters and if the previous commenter does not agree with the content then he/she may leave. The point that Diaries**** deliver to the previous commenter was that he/she must not follow gossip account if he/she cannot take any gossip about celebrity that he/she idolizes. From this one example, Diaries**** showed that he/she expressed the disagreement to the previous commenter. The previous commenter was also showing disagreement to the content that bully JD. Seeking disagreement was one form of positive impoliteness strategy which in this case was found in Instagram comment section.

2. Wand****** : Klo uda gt kasian tp keinget dy pelakor yaudalah itu 


\section{karmanya uda mnyakitin sesama wanita}

In this context Wand ${ }^{* * * * *}$ said that JD was a husband snatcher. JD has been well-known for her case of snatching someone else's husband. This case had become viral news in Indonesia. From this case, most of internet users especially @Lambe turah followers in Instagram have become JD haters. With that context, everything that happened to JD will be connected to her previous sin of snatching someone's husband away. This background also encouraged people to call JD with the other names, which is pelakor (husband snatcher). In @Lambe_turah post, it was common to find people call JD with pelakor. In other words, JD was commonly associated to the word 'pelakor'. This was shown by Wand****** statement above that he/she calls JD as pelakor. According to Culpeper (2005), calling someone using other name is considered as positive impoliteness. By using the other name, the addresser wanted to damage the face of JD.

\section{Negative Impoliteness}

The third impoliteness strategy is negative impoliteness. This strategy is used to damage the addressee negative face wants. According to Culpeper (2005), the behaviors that can be considered negative politeness of this model are condescending, contemptuous, do not treat other seriously, belittle the other and so on. Negative politeness was found 369 times in the findings with the percentage of $42.6 \%$. Based on Table 1, this strategy was the highest number. It indicated that negative impoliteness strategy was the most common way to perform cyberbullying. From some examples of negative impoliteness strategy that have been proposed by Culpeper (2005), belittling the other was found frequently. It can also be assumed that people tend to belittling someone when they perform cyberbullying. Some examples of negative impoliteness that were found in comment section is shown below:

1. syfana******* : Dia betah d'penjara...mka'a mau ngelakuin lgi wkhwkhwh

In syfana*******'s statement, the context was Jennifer Dunn had done similar cases with the current case that was about drug possession. In previous cases, JD had been jailed. But after being jailed, JD still repeated her mistake by possessing drug again. With this context, syfana*******felt irritated and said that JD might be enjoying her time while in prison because she repeated her mistake by consuming drugs again. syfana $* * * * * * *$ also added $w k w k w k$ which was an expression of laughing in CMC. Wkwkwk was also an expression of making fun of someone. In this case, it was used to make fun of JD. Moreover, syfana******* wanted to make fun of JD by saying that JD might be enjoying her time in prison. It is a common knowledge that being arrested in prison was never been enjoyable, but syfana******* wanted to 
belittle JD by saying the contradictive fact. This statement was intentionally written by syfana******* to make fun of JD. Belittling someone is considered as one behavior of negative impoliteness strategy.

\section{2. ovika******* : Duhh aciannn haha}

In the second example of negative impoliteness, the context is ovika******* commented on the arresting of JD by expressing mocking expression. Ovika******* said poor you with mocking intention. ovika******* would not mock or belittle JD if ovika******* liked JD, but the statement showed that ovika******* did not like or agreed with JD. It might be caused by JD's behavior from previous cases which were repeated drug possesion and JD's biggest sin that make JD well-known in @Lambe turah followers, snatching someone's husband away. For ovika*******, by doing those two big sins, snatching someone's husband and drug possession, JD needed to be punished and bullied. That had become the reason of why ovika******* was mocking and belittling JD in the comment. Culpeper (2005) said that behavior like belittling others is considered as one example of negative impoliteness strategy.

\section{3. misanie******* : Om kasihan aku om wkwkwkwk}

The context of the third example of negative impoliteness was misanie $* * * * * * *$ who wanted to mock JD based on the video of JD's arrestment. In that video, Jennifer Dunn knelt down and begs for mercy to the police. She apologized for possessing drugs in her house. The interesting aspect in the video was, JD was asking for pity to the police, but JD did not address to the police normally. Normally, people will call the police sir, but JD called the police uncle. So, instead of saying "sir, have mercy, sir", she said, "uncle, have mercy, uncle". For @Lambe_turah followers, this video was funny because not only they could see Jennifer Dunn with her expression while begging for mercy, they also make fun of how JD called the police. This video post had become viral news in Indonesia that one of commenter used this background to mock JD in the comment. The intention of misanie ${ }^{* * * * * * *}$ was to mock and belittle JD in front of other@Lambe_turah followers because most of people hates JD. According to Culpeper (2015), this behavior is considered as negative impoliteness.

4. Aldi***** : Suka kali bagian jedun duduk bersimpuh smbil mnta maaf min. Selalu di putar berulang ulang $\square$

The context in this fourth example of negative impoliteness was the post (video) on @lambe_turah account about a video when Jennifer Dunn got arrested. In that video, Dunn knelt down and begged for mercy to the police. She apologized for possessing drugs in her house. For Aldi***** and other @lambe_turah followers, this video was funny because they can see Jennifer Dunn with her expression while begging for mercy. For them, a celebrity like Jennifer Dunn who had already been jailed for 
similar cases (drugs possession) and getting caught for possessing drugs again became a source of fun. They thought one should stop from doing bad habit such as possessing and consuming drugs after being caught and jailed. However, what Jennifer Dunn showed had made them angry. Therefore, when Dunn was caught, they poured their anger by bullying her on the @lambe_turah's video post. The impoliteness strategy that was used by $A l d i * * * * *$ was belittling Jennifer Dunn by watching her knelt and begs for mercy over and over again. Act like belittling that was shown by $A l d i^{* * * * * *}$ above was considered as negative impoliteness as he wanted to damage the face of Jennifer Dunn.

\section{Sarcasm or Mock Politeness}

The fourth impoliteness strategy was sarcasm or mock politeness. This method is unique because it is insincere which does not directly state the real meaning. Mock is in this strategy is close to sarcasm that does not directly attack like mocking in negative impoliteness strategy. Differentiating both of them are a bit difficult. In this impoliteness strategy, the impoliteness is not shown obviously but more of something indirect. The addresser seems like saying something common but the statement might has other meaning to attack the addressee indirectly. This model was found 58 times with the percentage of $6.7 \%$. The example of sarcasm impoliteness strategy was shown below:

\section{1. mhm*******: Mungkin jedun belum dapat hidayah}

The context of $\mathrm{mhm}^{* * * * * * *}$ statement was that before getting arrest for drug possession, JD had done similar mistakes twice. After doing it twice, JD did not stop from doing her bad habit, but she repeated her mistake by possessing another drugs. The statement from mhm******* implied that JD might not get guidance from God so she still repeated her mistakes over and over again. The statement looked like usual comment but if it was related to the context, this statement was a sarcasm addressed to JD that she would never stop repeating her mistakes. $\mathrm{mhm}^{* * * * * * *}$ also implied that JD was enjoying her bad behavior by saying JD might not get the guidance from the God. Culpeper (2005) said that sarcasm or similar behavior which does not directly state the real meaning, if the intention is to damage the face of the addressee, is considered as impoliteness strategy.

\section{2. mug*******: Om pukul aku om $\square \square$ ngakakkk}

In this context, mug******* statement purposes to damage JD face using indirect way. This context was related to the condition that JD had been snatching someone's husband. With her father snatched away, the daughter of the husband angry to JD and they fought. The father even defended JD by hitting his daughter. From 
this event, the news spread widely in Indonesia and most people were angry to JD because of her fault the relationship between father and daughter was broken. After that event, JD was getting caught in other case related to drug possession. People who have bullied, mock, angry to JD because of the previous event, were happy that JD was getting arrested. They bully JD in social media, including the posts in @Lambe turah account. $m u g^{* * * * * * *}$ said "Uncle hit me, Uncle" to mock JD in indirect way. $m u g * * * * * * *$ recreated the condition when the father hit the daughter because of JD in the statement. Culpeper (2005) said that sarcasm or similar behavior which does not directly state the real meaning, if the intention is to damage the face of the addressee, is considered as impoliteness strategy.

\section{Withhold Politeness}

The last method of impoliteness is withhold politeness. This impoliteness strategy means the absence of politeness in a situation it must be shown. In the findings, this method was not found in Instagram cyberbullying. This finding also implied that cyberbullying performers are not familiar with the use withhold politeness at all. It may be caused that in cyberbullying, the addresser has no purpose to say gratitude to other people. They did not intend to show gratitude or politeness. Based on the findings, cyberbullying was done by deliberately damaging others' face so withhold politeness is never be used.

After discussing about the five impoliteness strategy proposed by Culpeper (2005) that were used by Instagram users to perform cyberbullying, the writer got interesting results. In the findings above, the impoliteness strategy that became the most common to be used to perform cyberbullying in CMC especially in Instagram was negative impoliteness (42.6\%). This was by far the most used impoliteness strategy. This might be influenced by the example of behavior of negative impoliteness which were condescending, contemptuous, do not treat other seriously, belittle and so on. These behaviors were used mostly in cyberbullying as people tend to belittling others when they perform cyberbullying.

The second most common impoliteness strategy used in cyberbullying was bald on record $(26.7 \%)$. This might be caused by the original purpose of performing cyberbullying was to attack and damage the addressee in a direct way. With this reason, the addresser tend to deliver the cyberbullying clearly and unambiguous.

The third impoliteness strategy that people likely to use when performing cyberbullying was positive impoliteness (24\%). As the third impoliteness strategy that people use when performing cyberbullying especially in Instagram, this strategy was less common compared to negative impoliteness and bald on record. This might be 
influenced by the behavior example of this strategy which were ignoring the other, excluding the other from an activity, being disinterested, unconcerned, unsympathetic, using inappropriate identity markers, using obscure or secretive language, seeking disagreement, using taboo words, calling the other names. People consider that these kinds of behavior were not strong enough to perform cyberbullying so they chose negative impoliteness and bald on record.

The last impoliteness strategy that was used by people when performing cyberbullying was sarcasm (6.7\%). Culpeper (2005) said that sarcasm or similar behavior which does not directly state the real meaning, if the intention is to damage the face of the addressee, is considered as impoliteness strategy. However, similar to positive impoliteness, people consider that this strategy was not strong enough to perform cyberbullying.

The last impoliteness strategy, withhold politeness was not found in any cyberbullying in the comments $(0 \%)$. This indicated that people tend to show the negative attitude clearly to the addresse when they are performing cyberbullying. It may be caused that in cyberbullying, the addresser had no purpose to say gratitude to other people.

\section{CONCLUSION}

The research analyzed the impoliteness strategies that were applied in Instagram cyberbullying. The cyberbullying was found in Instagram gossip account, @Lambe turah. In this gossip account, there are many posts that contain controversial news. One of the controversial news is about JD who was being arrested for possessing drugs. This has made netizens (Instagram users) triggered to bully JD in that post. People do not like JD because she has been considered as "Husband Snatcher". The research was conducted to find out how was the impoliteness strategy used by the cyberbullies participant in their comments when they were addressing JD or commenting to other Instagram users. The results showed that from five methods of impoliteness strategies, four of them were applied in cyberbullying while one of the methods were not.

The four methods that were used in giving comments were bald on record impoliteness, positive impoliteness, negative impoliteness, and sarcasm or mock politeness. The most used impoliteness strategy in Instagram cyberbullying was negative impoliteness. This was influenced by the factor that negative impoliteness was the best choice for Indonesian people to perform cyberbullying. They used this strategy which was designed to damage the addressee's negative face wants. They frighten, condescend, scorn or ridicule, be contemptuous, do not treat the other seriously, belittle the other, invade the other's space (literally or metaphorically), 
explicitly associate the other with a negative aspect (personalize, use the pronouns "I" and "You"), put the other's indebtedness on record. All of them were suited to be used in cyberbullying in Indonesia especially in Instagram because all of the criteria aimed to attack the addressee face. Although negative impoliteness was the highest number and the most common strategy in cyberbullying society, one of the method strategies, withhold politeness was not used at all in Instagram cyberbullies. This might be caused by the purpose of cyberbullying. Cyberbullying purposes to abuse, insult, offend which all of them do not match with the last impoliteness strategy, withhold politeness. Hopefully this research will give further insight of how cyberbullying is being performed in Instagram especially in Indonesia. The phenomena of Instagram users is very interesting that further study may continue the research to give better result and insight.

\section{REFERENCES}

Cyberbullying/Bullying Statistics. (2006, January 13). Retrieved from Statistic Brain: Percentages, Numbers, Financials, Rankings.: http://www.statisticbrain.com/ cyber-bullying-statistics/

Bousfield, D. (2008). Impoliteness in Interaction. Amsterdam: John Benjamins Publishing Company.

Creswell, J. W. (2009). Research Design: Qualitative, Quantitative, and Mixed Method Approaches 3rd ed. Los Angeles: Sage.

Culpeper, J. (2005). Impoliteness and Entertainment in the Television Quiz Show: The Weakest Link. Journal of Politeness Research 1, 35-72.

Culpeper, J. (2011). Impoliteness: Using Language to Cause Offence. Cambridge: Cambridge University Press.

Culpeper, J., Bousfield, D., \& Wichmann, A. (2003). Impoliteness Revisited: with Special Reference to Dynamic and Prosodic Aspects. Journal of Pragmatics $35,1545-1579$.

Erdur-Baker, Ö. (2010). Cyberbullying and its correlation to traditional bullying, gender and frequent and risky usage of internet-mediated communitaction tools. new media \& society, 109-125.

Hosseinmardi, H., Mattson, S. A., Rafiq, R. I., Han, R., Lv, Q., \& Mishra, S. (2015). Detection of Cyberbullying Incidents on the Instagram Social Network. arXiv preprint arXiv: 1503.03909.

Kemenkominfo. (2018, Januari 25). Kominfo : Pengguna Internet di Indonesia 63 
Juta Orang. Retrieved from Kementrian Komunikasi Dan Informatika Republik Indonesia: https://kominfo.go.id/index.php/content/detail/3415/ Kominfo+\%3A+Pengguna+Internet + di + Indonesia $+63+$ Juta + Orang/0/berita satker

Locher, M. A. (2010). Introduction: Politeness and Impoliteness in Computer-Mediated Communication. Journal of Politeness Research, 1-5.

Mey, J. L. (2001). Pragmatics: An Introduction. Massachussets: Blackwell Publishing.

Wade, A., \& Beran, T. (2011). Cyberbullying: The New Era of Bullying. Canadian Journal of School Psychology, 44-61.

Wibowo, G., \& Kuntjara, K. (2013). IMPOLITENESS STRATEGIES USED ON ONLINE COMMENTS IN AN INDONESIAN FOOTBALL WEBSITE. Student Journal Petra, 166-173.

Yule, G. (1996). Pragmatics. New York: Oxford University Press. 